\title{
Seminal Plasma Proteins: What Role Do They Play?
}

Heriberto Rodriguez-Martinez, Ulrik Kvist, Jan Ernerudh, Libia Sanz and Juan J. Calvete

\section{Linköping University Post Print}

N.B.: When citing this work, cite the original article.

This is the authors' version of:

Heriberto Rodriguez-Martinez, Ulrik Kvist, Jan Ernerudh, Libia Sanz and Juan J. Calvete, Seminal Plasma Proteins: What Role Do They Play?, 2011, AMERICAN JOURNAL OF REPRODUCTIVE IMMUNOLOGY, (66), , 11-22.

http://dx.doi.org/10.1111/j.1600-0897.2011.01033.x

Copyright: John Wiley and Sons http://www.wiley.com/

Postprint available at: Linköping University Electronic Press http://urn.kb.se/resolve?urn=urn:nbn:se:liu:diva-69810 


\section{Seminal plasma proteins: what roles do they play?}

Heriberto Rodríguez-Martínez, DVM, $\mathrm{PhD}^{1 \mathrm{a}}$, Ulrik Kvist, $\mathrm{MD}, \mathrm{PhD}^{2}$, Jan Ernerudh, MD, $\mathrm{PhD}^{1}$, Libia Sanz, $\mathrm{PhD}^{3}$ \& Juan J. Calvete, $\mathrm{PhD}^{3}$

${ }^{1}$ Department of Clinical \& Experimental Medicine (IKE), Faculty of Health Sciences, Linköping University, SE-581 85 Linköping, Sweden. E-mails: heriberto.rodriguezmartinez@liu.se; jan.ernerudh@lio.se

${ }^{2}$ Center for Andrology \& Sexual Medicine, Department of Medicine, Karolinska University Hospital/Huddinge, SE-14186 Stockholm, Sweden. E-mail: ulrik.kvist@ki.se ${ }^{3}$ Laboratory of Structural Proteomics, Institute of Biomedicine of Valencia, CSIC, Jaime Roig 11, 46010 Valencia, Spain. E-mails: libia.sanz@ibv.csic.es; jcalvete@ibv.csic.es

${ }^{a}$ Corresponding author: Prof. Dr. Heriberto Rodríguez-Martínez, Department of Clinical \& Experimental Medicine (IKE), Faculty of Health Sciences, Linköping University, Campus US, Lasarettsgatan 65, SE-581 85 Linköping, SWEDEN. Tel: +46-101032284, Fax: +461010334789, E-mail: heriberto.rodriguez-martinez@liu.se

Short title: Functions of seminal plasma proteins.

Key words: Ejaculate fractions, seminal plasma, proteomics, sperm function, immunemodulation, fertility. 


\section{Abstract}

Problem: Semen is a heterogenous and complex cell suspension in a protein-rich fluid with different functions, some of them well known, others still obscure.

Method of study: This paper reviews, comparatively, our current knowledge on the growing field of proteomics of the SP and its relevance in relation to the in vivo situation, for the sake of reproductive biology, diagnostics and treatment.

Results: Ejaculated spermatozoa, primarily bathing in cauda epidydimal fluid are (in vitro) bulky exposed to most, if not all secretions from the accessory sexual glands. In vivo, however, not all spermatozoa are necessarily exposed to all secretions from these glands, since sperm cohorts are delivered in differential order and bathe in seminal plasma (SP) with different concentrations of constituents, including peptides and proteins. Proteins are relevant for sperm function and relate to sperm interactions with the various environments along the female genital tract towards the oocyte vestments. Specific peptides and proteins act as signals for the female immune system to modulate sperm rejection or tolerance, perhaps even influencing the relative intrinsic fertility of the male and/or couple by attaining a status of maternal tolerance towards embryo and placental development.

Conclusions: Proteins of the seminal plasma have an ample panorama of action and some appear responsible for establishing fertility.

\section{Introduction}

Studies of the male reproductive organs pertaining their basic reproductive biology, for diagnostics of dysfunction or for treatment are often restricted to our capability to perform clinical examinations, alongside to collection of samples, especially in humans. A semen sample reflects the status of the testes, the excurrent ducts, and of the accessory sexual glands, being thus probably the most widely accessible material for most of the above purposes. Semen is classically defined as a fluid conglomerate, where spermatozoa and other cells (classically named round cells, either lining cells of the excurrent ducts, epididymis or accessory glands, migrating leukocytes, and even spermatogenic cells) and cell vesicles (epididymidosomes and prostasomes) are suspended in. Per definition, semen is thus divided in "cellular" and "acellular" components, the latter generically named seminal plasma (SP). The SP is built by the combined contribution of the fluids of the cauda epididymides and 
accessory sexual glands. Species of mammals differ regarding presence and size of accessory sexual glands which obviously lead to variations in their relative contribution to semen composition and volume, particularly regarding SP. In some species SP represents up to 95$98 \%$ of total semen volume ${ }^{1}$.

Methods for semen collection in human and other animals vary, including masturbation, digital collection, artificial vagina, electroejacualtion. Semen can be collected into a single (bulk sample) or into consecutive vials (split sample). In many species (e.g. human, stallion, canine, pigs to name a few) the ejaculate is void in spurts (also called jets) with different composition, owing to the sequential emission and/or emptying of secretion of the sexual accessory glands ${ }^{2}$. Therefore, semen composition -the SP in particular- also differs not only among species, among and within individuals but even within an ejaculate. Such differences are important when judging semen "quality". Quality is classically screened in terms of number of spermatozoa present, their motility and morphological "normality", the relative numbers of shed leukocytes (classically seen as signs of inflammatory changes), or of immature germ cells (as signs of defective spermatogenesis) etc. The SP of humans, but not of other species, is also examined, albeit not routinely, for specific markers (neutral $\alpha$ glucuronidase for epididymis fluid, phosphatases or zinc levels for prostate fluid, or fructose for seminal vesicles) $)^{3}$. The reluctance in examining SP is often related to the classical view that SP is a vehicle for spermatozoa, and even regarded as deleterious for some purposes, such as storage. For that reason, the SP is largely removed and replaced by extenders for further handling or freezing ${ }^{4}$.

However, growing evidence demonstrates the SP plays other roles, including modulation of sperm function, of their ability to interact with the epithelia and the secretions of the female genital tract and also as a carrier of signals for the female, its immune system in particular ${ }^{5-7}$. Simple components of the SP seem to play important roles for sperm viability. Bicarbonate modulates sperm motility and destabilizes the plasmalemma during capacitation ${ }^{8-9}$ while zinc modulates chromatin stability ${ }^{10}$. Most peptides and proteins of the SP, which often make up to 40-60 g/L per ejaculate (human 25-55 g/L; boar 30-60 g/L) play major other roles. Interestingly, the roles of seminal fluid protein appear to be highly conserved. In insects, transfer of seminal fluid, its proteins in particular, induces numerous physiological postmating changes, ranging from enhancement of egg production, modulation of sperm storage and competition, mating plug-formation and the expression of antimicrobial peptides. Moreover, 
seminal fluids appear to induce behavioural changes, including decreased receptivity to remating and modified feeding behaviour, with clear changes in female gene expression postmating for mating-dependent genes with predicted functions in metabolism, immune defense and protein modification ${ }^{11}$. Despite our filogenetical distance, mammals -including humans- also seem to ascribe exposure to SP-proteins other roles than serving as a nutrient and vehicle for spermatozoa, such as the induction of both innate and adaptative immunological responses by the female. These phenomena include the cleansing of eventually introduced pathogens and redundant allogeneic spermatozoa, while calling for immunotolerance towards tubal spermatozoa, developing embryos and feto-placental tissues, i.e. all components essential for reproductive success ${ }^{12}$.

Proteomics (e.g. the study of protein products expressed by the genome) has dramatically expanded over the past decade, owing to multidisciplinary methodological and instrumental developments, but also due to the central role of protein interactions in cell function ${ }^{13-14}$. Attempting to unravel these interactions requires direct studies of protein function, sometimes even bypassing genomic studies, considering the number of proteins present in mammals is 10-20 times higher than the number of protein-encoding genes (20-25,000). Presence of alternative splicing or post-translational modifications in proteins (such as glycosylation, phosphorylation, proteolytic processing, lipid modification, etc) explains these basic numerical differences. Interestingly, fluids such as semen appear, in the context of protein identification and relation to function, really complex, ranging from few relevant proteins in spermatozoa towards hundreds in $\mathrm{SP}^{15}$. Moreover, the fact that ejaculation is in many species fractionated adds a new dimension to the action of SP-proteins (and their interaction) on sperm function and on the female reactivity.

The present paper attempts to review aspects of the composition of the seminal plasma of mammals, with a particular focus on its proteomics and the differential functions this fluid would play in relation to sperm function and signalling to the female, with an ultimate focus on its role in modulating fertility.

\section{Ejaculation: deposition of a heterogenous ejaculate in the female}

As already mentioned, collection of a naturally fractionated ejaculate (as in humans, pigs or horses) into a single vial represents a non-physiological situation, since such bulk ejaculate, 
where all fluids mix at a single time does not exist in vivo. During coitus, individuals from these exemplified species deliver spurts of fluid in a sequential manner and to a specific location in the female. In primates and some artiodactila, sperm deposition is done deep in the vagina, in front of the cervical opening or in the vaginal fornix while in other species of ungulates, sperm deposition occurs intra cervically or even intrauterine ${ }^{2}$. The first secretion (pre-ejaculate) presented to the urethra is that of the urethral and/or bulbourethral glands (Littré and Cowper for human, a secretion containing mainly mucin, sialic acid, galactose and salts in a slightly viscous, clearly acqueous fluid). This is followed by the emission of spermatozoa from the caudae epididymides to the urethra accompanied by secretion from the prostate, followed by ejaculation proper (e.g expulsion of semen into the female) in a series of spurts. The initial spurts are usually called the sperm-rich fraction of the ejaculate, since most spermatozoa are present there ${ }^{16}$, with a blend of the acidic cauda epididymides and ampullar fluids together with the slightly acidic citrate and zinc-rich prostate fluid, which also contains specific peptides and proteins (as acid phosphatase and PSA in humans). In the following spurts, there is a gradual dominance of secretion from the seminal vesicles (rich in fructose, peptides, proteins, prostaglandins (PGs) etc, which is clearly basic in nature) $)^{2,17}$ as well as gradual diminution of sperm numbers ${ }^{6}$. Presence of PGs or hormones such as estrogens in the post sperm-rich fractions (vesicular-derived) is well documented, with large species variation $^{2}$. Some species (for instance boars and stallions) have a noticeable gel-rich secretion from the bulbourethral glands which can virtually coagulate the entire ejaculate if placed together, thus this component is deliberately removed during semen collection. In vivo, this gelifying fraction enters the cervical canal in these species by the end of ejaculation, a process also seen in other species ${ }^{18}$. In humans, at or immediately after ejaculation, a sample of semen collected in a single vial coagulates to form a gelatinous mass that immobilizes the spermatozoa. If an ejaculate is collected using a split procedure (i.e. several vessels for collection of different fractions), as it presumably occur in vivo, the first spurts (prostatedominated) do not coagulate, while the last ones (vesicular-dominated) do ${ }^{19}$. Such coagulum is rapidly (in vivo, within minutes) or more lengthy (15-30 min in vitro) liquefied by prostaticderived proteolytic enzymes ${ }^{20}$. Interestingly, most human spermatozoa are, as described, present in the first (non-coagulating) fractions, so a certain proportion of them can well rapidly enter the cervical canal, as extrapolated from studies which recorded sperm present in the Fallopian tubes as early as few minutes after coitus ${ }^{21}$, transport sustained by the myometrial and myosalpingeal contractions that characterize this period. Such phenomena seem clearly conserved among mammals ${ }^{22}$, suggesting that there might be a numerically 
restricted cohort of vanguard spermatozoa that can be relevant in establishing a sperm reservoir either in the cervical crypts and/or in the Fallopian tubes to warrant eventual fertilization $^{23-25}$. The other spermatozoa, including those trapped in a coagulum might well still be fertilizing, but time might play against them, since most spermatozoa are, together with the liquefied semen coagulum, flowbacked from the site of deposition via vagina, within minutes, in vivo ${ }^{26}$. Those spermatozoa not included in the female sperm reservoirs but yet having ascended to the uterus are considered foreign and thus phagocytosed by invading leukocytes, mosty in the form of polymorph-nuclear neutrophil granulocytes (PMNs) ${ }^{27}$.

\section{Proteomics of the ejaculate}

Proteomic studies of spermatozoa are limited. This situation is due to difficulties in separating spermatozoa from the round cells that might follow preparation of samples for analyses, something that can be easily solved by use of density separation or swim-up preparation techniques ${ }^{28}$. Spermatozoa are, by being so highly differentiated, advantageous cells to study proteomics of specific compartments such as the membrane, which basically is the area of major importance for its role in interacting with the surroundings and the oocyte. Comprehensive sperm protein databases had been established since the late $1990{ }^{\prime} \mathrm{s}^{29}$ with above 1,000 spots listed; a number that had increased over time ${ }^{15}$. Proteins identified thus far cover the expected spectrum of function (from energy-production to cell-recognition), but few, too few, are accurately linked to (in)fertility; thus calling for other methods of isolation of the membranes so that specific areas, relevant for capacitation or binding (either to the $\mathrm{ZP}$ or the oolema) are more closely examined ${ }^{14}$.

As for the SP, availability of seminal material has not been an issue since volumes are sufficient for analyses for either human or animal studies. Moreover, sampling methods can be refined for examination of other portions than the bulk ejaculate, such as specific fractions or even specific accessory glands (for instance after massage expression of prostate, seminal vesicles, etc). Neither does the protein content matter, since proteins are a major component, throughout species. Major SP-proteins belong to one of three main groups: proteins carrying fibronectin type II (Fn-2) modules, spermadhesins or cysteine-rich secretory proteins $(\text { CRISPs })^{30}$. However, differences in type and source of proteins are present among species, owing to the already named differences in glands and/or the sequence they are emptied; or the 
type of ejaculate they have. In most species, proteins are mainly of vesicular gland origin, and in ungulate mammals (boar, stallion, bull, buck) most proteins are Fn2 and/or spermadhesins $^{30-31}$. Spermadhesins have been most thoroughly studied in pig SP, as a family built by three members; the Alanine-Glutamine-Asparagine proteins AQN (-1 and -3$)$, the Alanine-Tryptophan-Asparagine proteins [AWNs] and the porcine seminal plasma proteins I and II [PSP-I and PSP-II $]^{32}$.

Spermadhesins are multifunctional 12-16 kDa glycoproteins whose biological activities depend on their sequence, grade of glycosylation or aggregation state, as well as on their ability to bind heparin (AQN-1, AQN-3 and AWN, grouped as heparin-binding proteins [HBPs]) or not (PSPs), as they attach in varying degree, to the sperm plasma membrane, from the testis to the ejaculate. Collectively, they have been related to multiple effects on spermatozoa including membrane stabilization, capacitation, and interplay between spermoviductal lining or sperm-ZP. The HBPs seem to stabilize the plasma membrane over the acrosome prior to capacitation ${ }^{33}$. Detection of AWN-epitopes on boar spermatozoa bound in vivo to the ZP strongly suggests the protein mediates sperm-ZP interaction ${ }^{34}$. While HBPs do not seem to promote sperm survival, at least in vitro ${ }^{35}$, the non-heparin-binding PSP-I and PSP-II ${ }^{36,37}$, which account for $>50 \%$ of all SP-proteins and forms a glycosylated heterodimer ${ }^{38}$, which binds to the sperm surface and displays protective action on highlyextended and processed spermatozoa ${ }^{39,40}$. The PSPs depict, moreover, clear immunostimulatory activities in vitro and in vivo, presumably in relation to specific cytokines $^{6,7}$.

Within a boar ejaculate, protein amounts increase 4-fold alongside the secretion of the vesicular glands, so that relative protein concentrations are low in the pre-sperm fraction and the first portion of the sperm-rich fraction (called sperm-peak portion), to increase (most HBPs and, particularly the PSPs) towards the end of the ejaculate (See Figure 1). In the sperm-peak portion (first-fraction), where most spermatozoa are present, other proteins, presumably of epididymal origin, such as Lipocalins and inhibitor of acrosin/trypsin are detected $^{6}$. In other species, such as the stallion, protein amounts follow a similar disposition and main SP-proteins are equivalent; Fn-2, CRISPs and spermadhesins. These proteins, initially described as horse seminal protein (HSP)-1 to HSP-8, are mostly of low molecular weight (14-30 kDa) forming multi-protein aggregates, which -with the exception of HSP-4attach to the sperm surface ${ }^{41}$. The two major proteins, the heparin-binding HSP-1 and HSP-2, 
accounted for $70-80 \%$ of the total protein, and were considered modulators of capacitation. Both HSP-1 and HSP-2 (also called SP-1 and SP-2) are short Fn-2 type proteins, similar to the major bovine heparin-binding proteins (BSP), also associated with capacitation ${ }^{42}$. These Fn-2 type proteins bind to phosphatidylcholine or sphingomyelin phospholipids of the ejaculated sperm membrane, causing changes in the membrane structure ${ }^{43,44}$. The HSP-3 (or equine CRISP-3) is associated to fertility ${ }^{45}$ perhaps via its role as selective protector against PMNcell binding ${ }^{46}$. Examining fractions of the equine ejaculate, the first fractions contained acrosine inhibitor and prostate specific antigen (PSA), or kallikrein-like proteins (as HSP-6 and HSP-8 representing isoforms), yet with all HSPs being present in the rest of the fractions and HSP-1 being the major protein present in all ejaculate fractions ${ }^{47}$. HSP-7 is the only member of the spermadhesin family, and like its porcine homologue AWN-1, shows ZPbinding activity ${ }^{48}$.

Human SP is also a rich source of proteins and phosphatases, aminopeptidases, glycosidases, hyaluronidase, mucin etc have been detected more than 50 years ago ${ }^{15}$. Since then, more and more spots have been identified, and SP-proteins corresponding to the same parent protein appear in multiple spots and bands, implying that there is a clear multiplicity of isoforms present, independently of the SP-source (expressed prostate ${ }^{49,50}$ ), or the bulk ejaculate ${ }^{51}$. Thousands of unique proteins have over time been identified, of which $\sim 25 \%$ were secretory ${ }^{52,53}$. The major accessory glands of men contribute differentially to the SP-protein pool. The major protein constituents of the seminal vesicle fluid are mainly semenogelin I but also semenogelin II, involved in the gelification of the latter spurts of the ejaculate (coagulum) and, following liquefaction, yielding products with clear biological functions such as inhibiton of sperm motility, antibacterial activity etc alongside with other seminal vesicle proteins that include lactoferrin, fibronectin and protein C-inhibitor ${ }^{15}$. Unfortunately, seminal vesicle secretions are rarely examined alone, unless split ejaculates are used, in contrast to secretions from the human prostate, which are more commonly studied via gland expression per rectum. Prostate secretions, albeit only representing 20-30\% of the total SP-volume, are in direct and immediate contact with the major numbers of spermatozoa, and are the first SPportion to confront the cervical canal. The protein contents consists of three major proteins, all under hormone regulation: Prostate-Specific Antigen (PSA, Zinc-binder, Kallikrein family, mainly released in prostasomes but also produced by the Littré glands), prostatic acid phosphatase and the cysteine-rich prostate-specific protein-94 (PSP-94, $\beta$-inhibin- $\beta$ microseminoprotein $)^{54,55}$. PSA primary function is the liquefaction of the coagulum by 
hydrolyzing semenogelins while prostatic acid phosphatase and the PSP-94 have enzymatic respectively growth factor action. As per the Cowper's gland (which is difficult to sample isolated) it contains an extremely abundant protein: mucin ${ }^{2}$. As well, peptides are a major component of the SP albeit most of them are either fragment products of SP-proteins or sperm-associated peptide hormones ${ }^{15}$. Other enzymes are also present in the SP, such as glycosidases ( $\beta$-glucuronidase (BG), $\alpha$-glucosidase, $\beta$-glucosidase, $\alpha$-galactosidase, $\beta$ galactosidase and $\beta-\mathrm{N}$-acetylglucosaminidase (NAG), etc $)^{2}$. Lipocalin-type prostaglandin D2 synthase, an enzyme present in the stallion and boar SP, is of epididymal origin ${ }^{6,56}$, and related to male fertility ${ }^{57-59}$. Other enzymes, such as lipases ${ }^{60}$ or matrix metalloproteinases (MMPs) relate to semen quality ${ }^{61,62}$.

In addition to enzymes, the SP of most species contains protein compounds similar to those present in blood plasma, such as pro-albumin, albumin, $\alpha-, \beta$ - and $\gamma$-globulins, transferrin, some immunoglobulins, complement factors and differential amounts of cytokines and chemokines $^{63-66}$, as studied in thawed SP derived from individual or pooled whole ejaculates post-licquefaction. Whether these cytokines are related to inflammation in the male genital tract (i.e. prostatitis ${ }^{67}$ ) or are in direct relation to presence and amounts of shed leukocytes ${ }^{68-69}$ remains to be fully studied. Besides, there are specific amounts of pro- and anti(or tolerancerelated)-cytokines (see below) ${ }^{70,71}$. Moreover, there are differences regarding their source, which calls for differential studies of ejaculate fractions. In that direction, we have studied SP of different categories of human samples grouped as (i) whole ejaculates (control) (ii) samples with low-zinc levels, eg vesicular vesicle-dominated samples, (iii) ejaculates from men with agenesia of the seminal vesicles, eg prostata-dominated secretion and, (iv) ejaculates postvasectomy, eg without sperm-, testicular or epididymal fluid exposure, and detected a rather large number of cytokines and chemokines. The pro-inflammatory CXCL8 (ex-IL-8) and GRO (CXCL1/Th17); as well as the anti-inflammatory or tolerating monocyte-recruiting protein 1 (MCP-1/CCL2), IP-10 (CXCL10/Th1), M-CSF (M2 inductor) or the immunedeviating transforming growth factor- $\beta$ (TGF $\beta$ ) isoforms (1-3) were among those in highest concentrations $(0.5-300 \mathrm{ng} / \mathrm{mL})$, thus being most reliably measurable. Both pro-inflammatory (TNF, IFN- $\gamma$, IL-6, IL-8, GM-CSF), and anti-inflammatory cytokines (TARC, M-CSF) were highest in vesicular-dominated fractions. Not surprising, leukocyte (PMN)-counts correlated with the relative levels of TNF, IL-6 and CXCL8 (ex-IL-8) but not with those of TGF $\beta 1-3$. Consequently, anti-inflammatory and tolerance-related cytokines (IL-10, LIF, M-CSF), but not of TGF $\beta 1-3$, dominated in samples with few leukocytes, being their relative concentration 
lowest in leukocytic samples $(>1$ million/mL). These preliminary results suggest differences in cytokine/chemokine levels among fractions of the human ejaculate which might be related to specific signaling properties in vivo.

\section{Functions of SP-proteins}

The suggested functions of SP proteins include their involvement in several essential steps preceding fertilization, such as regulating capacitation, establishment of the oviductal sperm reservoir, modulation of the uterine immune response, and sperm transport in the female genital tract, as well as in gamete interaction and fusion ${ }^{42}$. Interestingly, individual proteins from the same family appear to function in a species-specific manner. Differences in their structure, relative abundance and patterns of expression appear to determine species-specific effects of homologous proteins ${ }^{31}$. SP-proteins differ somewhat in functionality related to their source, more clearly seen when fractionated ejaculates are examined.

\section{Sperm transport and survival}

Following mating or intercourse, mammalian spermatozoa are transported from the site of deposition towards the oviduct within minutes, owing to the concerted motility of the female tract muscle ${ }^{72}$. These spermatozoa bathe, in individuals with fractionated ejaculation, in different fluids, such as the epididymal cauda fluid and the accessory gland secretion that is verted at the time the corresponding spurt of ejaculation is issued. As mentioned before, the secretion of the first spurts of the sperm-rich fraction is acidic, and sperm proteins demonstrated to link themselves to acidic polysaccharides such as those in the secretion of the cervix, uterus and even oviduct ${ }^{8}$. On the other hand, binding of some SP-proteins, at least in the bull and stallion, inhibits such interaction of sperm proteins with acidic polysaccharides ${ }^{73}$. SP-proteins affect differentially sperm survival post ejaculation, and those present in the the last ejaculate fractions (seminal vesicle origin) have a more pronounced negative effect, perhaps in relation to the extensive presence of several proteins. For instance, cleavage products of the human ejaculate coagulum (basically vesicular secretion) inhibit sperm motility (see above), which indicates those spermatozoa might be in disadvantage in vivo. The primary secretion in the first spurts, however, where spermatozoa are present, promotes longer sperm survival in humans ${ }^{16}$ and boars ${ }^{5,6}$. Remarkably, both these species contains prostasomes, known by their ability to fuse with spermatozoa and provide a mechanism for 
protein and lipid transfer ${ }^{55}$, thus enhancing sperm motility and stabilizing the sperm membrane. Comparative studies in pigs have shown porcine SP-proteins influences sperm physiology ${ }^{5}$. As such, HBPs play a major role during sperm transport ${ }^{33}$ while the heterodimer PSP-I/PSP-II maintains fertilising capacity ${ }^{40,74}$. This beneficial effect depends on the PSP-II moiety, active at doses as low as $0.75 \mathrm{mg} / \mathrm{mL}^{39}$, concentrations present in the first spurts of the boar ejaculate.

\section{Protein interaction with the female genital tract and the oocyte}

As listed above, porcine HBPs spermadhesins coat the sperm membrane during ejaculation, producing structural changes to the sperm plasma membrane in relation to capacitation, $\mathrm{ZP}$ recognition and fertilization. AWN follows, for instance, the spermatozoa up to the $\mathrm{ZP}^{34}$, perhaps due to their role in inhibiting sperm capacitation ${ }^{75,76}$, an effect that is lost when this protein is removed from the sperm surface ${ }^{33}$. At the same time, such initial layer of proteins might provide an anchor for aggregated spermadhesins to further coat the sperm surface ${ }^{77}$, further stabilizing the plasmalemma and preventing premature acrosomal exocytosis. The heparin binding AQN-3, the most prominent ZP-binding protein in boar spermatozoa remains -for instance- attached to the sperm surface after capacitation (in vitro) and can only be recovered from the aggregating raft area of the apical ridge of the sperm head ${ }^{78,79}$. The nonheparin binding protein PSP-I prevents premature capacitation and acrosome exocytosis (see above $)^{80}$. Whether these proteins are also involved in the interaction between spermatozoaand oviductal epithelium during sperm capacitation remains to be explored.

Increasing evidence exist that SP-proteins are able to interact with the vaginal, cervical and, particularly, the uterine epithelium to elicit a series of changes in the immune responsiveness of the female, apparently modulated by pro- and anti-inflammatory SP-proteins ${ }^{81}$. This is not surprising, since the ejaculate (spermatozoa and SP) is to be considered foreign by the female and thus prompt to rejection. Deposition of semen into the vagina or the uterine cavity elicits a massive invasion of PMNs toward the lumen, followed by formation of neutrophil extracellular traps (NETs) and sperm phagocytosis. Although PMN presence and infiltration are estrogen-dependent ${ }^{82}$, PMN migration to the surface epithelium and lumen can be elicited by SP-glycoproteins (spermadhesins ${ }^{7}$ ) and pro-inflammatory soluble cytokines ${ }^{83}$, see Figure 2. This primary inflammatory reaction cleanses the intra-uterine lumen from foreign cells, proteins and eventual pathogens, in preparation for the descending embryo. On the other 
hand, it does not occur in the oviduct, where spermatozoa find a haven until fertilization ${ }^{8,9,27}$. Induction of PMN invasion is, evidently, not the only effect of the SP on the female.

The SP also mitigates the female immune responses to paternal antigen-bearing spermatozoa or early embryos in the oviduct (immuno-privileged area) or in the uterus (developing embryos/fetuses and their placentae), by eliciting a transient state of peripheral immune tolerance ${ }^{82,84,85}$. The SP of boars and humans contains immune-regulatory molecules, including high concentrations of the potent immune-deviating TGF- $\beta$ (particularly TGF- $\beta 1$, but also TGF 32 - and 3 isoforms) a member of the multifunctional cytokine TGF family ${ }^{86,87}$. TGFß1-concentrations are higher than in other body fluids, as blood plasma or breast milk, and similar to colostrum levels ${ }^{88}$, reaching $120-150 \mathrm{ng} / \mathrm{mL}$ in boar semen ${ }^{87}$ or even higher levels in human bulk ejaculates $(\sim 150-200 \mathrm{ng} / \mathrm{mL})$ most of it being the latent (inactive) form and solely 1-2 ng/mL being the short-lived active form ${ }^{65,89}$. The origin of the human TGF- $\beta 1$ latent form is yet discussed, while TGF- $\beta 3$ is apparently synthetized by the prostate as levels are highest in semen from men with agenesia of the seminal vesicles and lowest in samples there the seminal vesicle secretion dominates (Rodriguez-Martinez et al. unpublished). The latent forms can be converted to its active form under acidic conditions (as in the vagina) or by SP-acid enzymes upon ejaculation, and be then more firmly attached to the sperm postacrosomal membrane ${ }^{87,90}$. TGF- $\beta$ seems to induce the differentiation and expansion of the bank of regulatory $\mathrm{T}$ (Treg) cells, a 5-10\% sub-population of suppressor CD4+ T-cells, to reach a state of adaptative functional immune maternal tolerance to male antigens ${ }^{84,91-92}$.

Males differ in their SP-contents of TGF- $\beta$, without straight relation to fertility ${ }^{86,89}$. However, a female could express different levels of endogenous cytokines depending on the exposure to SP from different males, which might thus relate to the often-observed differences in embryo survival among sires (e.g. innate fertility), a real long-lasting effect of the SP on the female $^{12,93}$. Whether such mechanism is valid also for humans remains to be fully elucidated, but clinical evidence exists that fertility after ART is enhanced by accompanying unprotected intercourse or vaginal exposure to homologous $\mathrm{SP}^{12}$. Interesting is the circumstantial evidence that the latent form of TGF- $\beta-2$ (as for TGF- $\beta 1$ ) could also have a preferential production by the epithelium of the prostate ${ }^{94}$. Whether both are activated by PSA in relation to differences among males (or females) is yet to be tested. 
SP-proteomes have been assessed in relation to reproductive outcomes (either fertility levels or (in)fertility, in several species of mammals, particularly domestic animals but also human. SP-proteins have been identified as associated with high, respectively low fertility in bulls ${ }^{95}$, isolated as osteopontin (OPN) and Lipocalin-Type Prostaglandin D synthase ${ }^{96,97}$. The latter has been always present in the sperm-rich spurts of ejaculates in species (including humans) with fractionated ejaculation. OPN has been related to fertility in pigs (in vitro fertilization $^{98,99}$ ) and stallions ${ }^{100}$. Three proteins (SP-2, SP-3 and SP-4) were found in higher concentrations in stallions with low fertility scores, while SP-1 was positively correlated with fertility and was suggested to be homologous to $\mathrm{OPN}^{95}$. The spermadhesin PSP-I, common in pigs, seems negatively related to fertility ${ }^{58}$ while other molecules, such as TGF $\beta$, appear unrelated to overall fertility in relation to levels in semen ${ }^{89}$. However, since the SP of a boar differs somehow from that of another boar, maybe it is not the amount of the cytokine that play the major role, but its capacity to differentially induce degrees of maternal tolerance by the female and thus attain differences in embryo survival, leading to variation in fertility. It is hoped that this line of research is followed.

\section{Conclusions}

Proteins of the seminal plasma are relevant for sperm function particularly for their interactions with the various environments of the tubular genital tract and the oocyte and its vestments. Moreover, specific peptides and proteins act as signals for the immune system of the female, ultimately modulating sperm rejection or tolerance, perhaps even influencing the relative intrinsic fertility of the male and/or couple.

\section{Ackowledgments}

Funding has been provided by The Swedish Research Councils Vetenskapsrådet (VR) and FORMAS, Stockholm, Sweden; and BFU2010-17373, Valencia, Spain. 


\section{References}

1. Beyler SA, Zaneveld LJD: The male accessory sex glands. In: Biochemistry of mammalian reproduction. Eds: Zaneveld LJD, Chatterton RT. John Wiley \& Sons, NY, USA. 1982; 65-88.

2. Mann T, Lutwak-Mann C: Male Reproductive Function and Semen. First edition. New York: Springer-Verlag Berlin Heidelberg, 1981.

3. WHO Laboratory Manual for the Examination and Processing of Human Semen. Cambridge: WHO Press, 5th edition, 2010, $271 \mathrm{pp.}$

4. Rodriguez-Martinez H, Barth $\mathrm{AD}$ : In vitro evaluation of sperm quality related to in vivo function and fertility. In: Reproduction in Domestic Ruminants VI. Edited by JI Juengel, JF Murray and MF Smith. Nottingham University Press, Nottingham, UK, 2007;39-54 (Soc Reprod Fert 64: 39-54, 2007).

5. Rodríguez-Martinez H, Saravia F, Wallgren M, Roca J, Peña FJ: Influence of seminal plasma on the kinematics of boar spermatozoa during freezing. Theriogenology 2008;70:1242-1250.

6. Rodriguez-Martinez H, Kvist U, Saravia F, Wallgren M, Johannisson A, Sanz L, Peña FJ, Martinez EA, Roca J, Vazquez JM, Calvete JJ: The physiological roles of the boar ejaculate. In: "Control of Pig Reproduction VIII" eds H Rodriguez-Martinez, JL Vallet, AJ Ziecik. Nottingham University Press, UK, 2009:1-21 (ISBN 978-1-904761-39-6).

7. Rodriguez-Martinez H, Saravia F, Wallgren M, Martinez EA, Sanz L, Roca J, Vazquez JM, Calvete JJ: Spermadhesin PSP-I/PSP-II heterodimer induces migration of polymorphonuclear neutrophils into the uterine cavity of the sow. J Reprod Immunol 2010;84:57-65.

8. Rodriguez-Martinez H, Tienthai P, Suzuki K, Funahashi H, Ekwall H, Johannisson A: Oviduct involvement in sperm capacitation and oocyte development. Reproduction Suppl 2001;58:129-145.

9. Rodriguez-Martinez H, Saravia F, Wallgren M, Tienthai P, Johannisson A, Vázquez JM, Martínez E, Roca J, Sanz L, Calvete JJ: Boar spermatozoa in the oviduct. Theriogenology 2005;63:514-535.

10. Björndahl L, Kvist U: Human sperm chromatin stabilization: a proposed model including zinc bridges. Mol Human Reprod 2010;16: 23-29. 
11. Avila FW, Sirot LK, LaFlamme BA, Rubinstein CD, Wolfner MF: Insect seminal fluid proteins: identification and function. Annu Rev Entomol 2011;56:21-40.

12. Robertson SA: Immune regulation of conception and embryo implantation-all about quality control? J Reprod Immunol 2010; 85:51-57.

13. Cox J, Mann M. Is proteomics the new genomics? Cell 2007;130:395-398.

14. Brewis IA, Gadella BM: Sperm surface proteomics: from protein lists to biological function. Mol Human Reprod 2010;16:68-79.

15. Duncan MW, Thompson HS: Proteomics of semen and its constituents. Proteomics Clin Appl 2007;1:861-875.

16. Purvis K, Magnus $\mathrm{O}$, Morkås L, Abyholm T, Rui H: Ejaculate composition after masturbation and coitus in the human male. Int J Androl 1986;9:401-406.

17. Owen DH, Katz DF: A review of the physical and chemical properties of human semen and the formulation of a semen simulant. J Androl 2005;26:459-469.

18. Dixson AL, Andersson MJ: Sexual selection, seminal coagulation and copulatory plug formation in primates. Folia Primatl (Basel) 2002; 73:63-69.

19. Yoshida K, Kawano N, Yoshihike M, Yoshida M, Iwamoto T, Morisawa M: Physiological roles of semenogelin I and zinc in sperm motility and semen coagulation on ejaculation in humans. Mol Hum Reprod 2008;14:151-156.

20. Jonsson M, Linse S, Frohm B, Lundwall A, Malm J: Semenogelins I and II bind zinc and regulate the activity of prostate-specific antigen. Biochem J 2005;387:447-453.

21. Sobrero AJ, McLeod J: The immediate postcoital test. Fertil Steril 1997;13:184-189.

22. Rodriguez-Martinez H: Role of the oviduct in sperm capacitation. Theriogenology 2007b;68: 138-146.

23. Hunter RH: Human fertilization in vivo, with special reference to progression, storage and release of competent spermatozoa. Hum Reprod 1987 2:329-332.

24. Suarez SS, Pacey AA: Sperm transport in the female reproductive tract. Human Reprod Update 2006;12:23-37.

25. Wallgren M, Saravia F, Rodriguez-Martinez H: The vanguard sperm cohort of the boar ejaculate is overrepresented in the tubal sperm reservoir in vivo. J Reprod Dev 2010;56:68-72.

26. Baker RR, Bellis MA: Human sperm competition: ejaculate manipulation by females and a function of the female orgasm. Anim Behav 1993;6:887-909.

27. Rodriguez-Martinez H, Nicander L, Viring S, Einarsson S, Larsson K: Ultrastructure of the uterotubal junction in preovulatory pigs. Anat Histol Embryol 1990;19:16-36. 
28. Rodriguez-Martinez H, Larsson B, Pertoft H: Evaluation of sperm damage and techniques for sperm clean-up. Reprod Fertil Dev 1997;9:297-308.

29. Naaby-Hansen S, Flickinger CJ, Herr JC: Two dimensional gel electrophoresic analysis of vectorially labeled surface proteins of human spermatozoa. Biol Reprod 1997;56:771-787.

30. Kelly VC, Kuy S, Palmer DJ, Xu Z, Davis SR, Cooper GJ: Characterization of bovine seminal plasma by proteomics. Proteomics 2006;6:5826-5833.

31. Calvete JJ, Sanz L: Insights into structure-function correlations of ungulate seminal plasma proteins. Soc Reprod Fertil Suppl 2007;65:201-215.

32. Töpfer-Petersen E, Romero A, Varela PF, Ekhlasi-Hundrieser M, Dostàlovà Z, Sanz L, Calvete JJ: Spermadhesins: a new protein family. Facts, hypotheses and perspectives. Andrologia 1998;30:217-224.

33. Calvete JJ, Ensslin M, Mburu J, Iborra A, Martínez P, Adermann K, Waberski D, Sanz L, Töpfer-Petersen E, Weitze K-F, Einarsson S, Rodríguez-Martínez H: Monoclonal antibodies against boar sperm zona pellucida-binding protein AWN-1. Characterization of a continuous antigenic determinant and immunolocalization of AWN epitopes in inseminated sows. Biol Reprod 1997;57:735-742.

34. Rodríguez-Martínez H, Iborra A, Martínez P, Calvete JJ: Immunoelectronmicroscopic imaging of spermadhesin AWN epitopes on boar spermatozoa bound in vivo to the zona pellucida. Reprod Fertil Dev 1998;10:491-497.

35. Centurión F, Vazquez JM, Calvete JJ, Roca J, Sanz L, Parrilla I, Garcia EM, Martinez EA: Influence of porcine spermadhesins on the susceptibility of boar spermatozoa to high dilution. Biol Reprod 2003;69:640-646.

36. Manaskova P \& Jkanova V: Localization of porcine seminal plasma (PSP) proteins in the boar reproductive tract and spermatozoa. J Reprod Immunol 2008;78:40-48.

37. García EM, Vázquez JM, Parrilla I, Ortega MD, Calvete JJ, Sanz L, Martínez EA, Roca J, Rodríguez-Martínez H: Localization and expression of spermadhesin PSP-I/PSP-II subunits in the reproductive organs of the boar. Int J Androl 2008;31:408-417.

38. Calvete JJ, Sanz L, Garcia EM, Caballero I, Parrilla I, Martinez EA, Roca J, Vazquez JM, Saravia F, Wallgren M, Johannisson A, Rodriguez-Martinez H: On the biological function of boar spermadhesin PSP-I/PSP-II. Reprod Domest Anim 2005;40:331 (W3.1).

39. García EM, Vázquez JM, Calvete JJ, Sanz L, Caballero I, Parrilla I, Gil MA, Roca J, Martinez EA: Dissecting the protective effect of the seminal plasma permadhesin PSPI/PSP-II on boar sperm functionality. J Androl 2006;27:434-443. 
40. Caballero I, Vazquez JM, Garcia EM, Parrilla I, Roca J, Calvete JJ, Sanz L, Martinez EA: Major proteins of boar seminal plasma as a tool for biotechnological preservation of spermatozoa. Theriogenology 2008;70:1352-1355.

41. Calvete JJ, Nessau S, Mann K, Sanz L, Sieme H, Klug E, Töpfer-Petersen E: Isolation and Biochemical characterization of stallion seminal-plasma proteins. Reprod Domest Anim 1994;29:411-426.

42. Töpfer-Petersen E, Ekhlasi-Hundrieser M, Kirchhoff C, Leeb T, Sieme H: The role of stallion seminal plasma proteins in fertilisation. Anim Reprod Sci 2005;89:159-170

43. Greube A, Müller K, Töpfer-Petersen E, Herrmann A, Müller P: Interaction of fibronectin type II proteins with membranes: the stallion seminal plasma protein SP-1/2. Biochemistry 2004;43:464-472.

44. Ekhlasi-Hundrieser M, Schäfer B, Kirchhoff C, Hess O, Bellair S, Muller P, TöpferPetersen E: Structural and molecular characterization of equine sperm-binding fibronectin-II module proteins. Mol Reprod Dev 2005;70:45-57.

45. Hamann H, Jude R, Sieme H, Mertens U, Töpfer-Petersen E, Distl O, Leeb T: A polymorphism within the equine CRISP3 gene is associated with stallion fertility in Hannoverian warmblood horses. Anim Genet 2007;38:259-264.

46. Troedsson MHT, Doty A, Macpherson ML, Connor MC, Verstegen JP, Pozor MA, Buhi WC: CRISP-3 in equine seminal plasma is involved in selective uterine sperm transport. Anim Reprod Sci 2010;121: 192-193.

47. Kareskoski AM, Rivera del Alamo MM, Güvenc K, Reilas T, Calvete JJ, RodriguezMartinez H, Andersson M, Katila T: Protein composition of seminal plasma in fractionated stallion ejaculates. Reprod Domest Anim 2011;46:e79-84.

48. Reinert M, Calvete JJ, Sanz L, Mann K, Töpfer-Petersen E: Primary structure of stallion seminal plasma protein HSP-7, a zona-pellucida binding protein of the spermadhesin family. Eur J Biochem 1996;242:636-640.

49. Drake RR, White KY, Fuller TW, Igwe E, Clements MA, Nyalwidhe JO, Given RW, Lance RS, Semmes OJ: Clinical collection and protein properties of expressed prostatic secretions as a source for biomarkers of prostatic disease. J Proteom 2009;72:907-917.

50. Drake RR, Elschenbroich A, Lopez-Perez O, Kim Y, Ignatchenko V, Ignatchenko A, Nyalwidhe JO, Basu G, Wilkins CE, Gjurich B, Lance RS, Semmes OJ, Medin JA, Kislinger T: In-depth proteomic analyses of direct expressed prostatic secretions. $J$ Proteom Res 2010;9:2109-2116. 
51. Fung KYC, Glode LM, Green S, Duncan MW: A comprehensive characterization of the peptide and protein constituents of human seminal fluid. The Prostate 2004;16:171-181.

52. Pilch B, Mann M: Large-scale and high-confidence proteomic analysis of human seminal plasma. Genome Biol 2006;7:R40-49.

53. Batruch I, Lecker I, Kagedan D, Smith CR, Mullen BJ, GRober E, Lo KC, Diamandis EP, Jarvi KA: Proteomic analysis of seminal plasma from normal volunteers and postvasectomy patients identifies over 2000 proteins and candidate biomarkers of the urogenital system. J Proteome Res 2011 (in press, doi/10.1021/pr100745u)

54. Utleg AG, Yi EC, Xie T, Shannon P, White JT, Goodlett DR, Hood L, Lin B: Proteomic analysis of human prostasomes. The Prostate 2003;56:150-161.

55. Burden HP, Holmes CH, Persad R, Whittington K: Prostasomes-their effects on human male reproduction and fertility. Human Reprod Update 2006;12:283-292.

56. Fouchécourt S, Métayer S, Locatelli A, Dacheux F, Dacheux J-L: Stallion epididymal fluid proteome: Qualitative and quantitative characterization; secretion and dynamic changes of major proteins. Biol Reprod 2000;62: 1790-1803.

57. Barrier-Battut I, Dacheux JL, Gatti JL, Rouviere P, Stanciu C, Dacheux F, Vidament M, 2005: Seminal plasma proteins and semen characteristics in relation with fertility in the stallion. Anim Reprod Sci 2005;89:255-258.

58. Novak S, Smith TA, Paradis F, Burwash L, Dyck MK, Foxcroft GR, Dixon WT: Biomarkers of in vivo fertility in sperm and seminal plasma of fertile stallions. Theriogenology 2010;74:956-967.

59. Novak S, Ruiz-Sanchez A, Dixon WT, Foxcroft GR, Dyck MK: Seminal plasma proteins as potential markers of relative fertility in boars. $J$ Androl 2010;31:188-200.

60. Carver DA, Ball BA, 2002: Lipase activity in stallion seminal plasma and the effect of lipase on stallion spermatozoa during storage at $5{ }^{\circ} \mathrm{C}$. Theriogenology 58 1587-1595.

61. Baumgart E, Lenk SV, Loening SA, Jung K: Quantitative differences in matrix metalloproteinase (MMP)-2, but not in MMP-9, tissue inhibitor of metalloproteinase (TIMP)-1 or TIMP-2, in seminal plasma of normozoospermic and azoospermic patients. Hum Reprod 2002;17:2919-2923.

62. Buchman-Shaked O, Kraiem Z, Gonen Y, Goldman S: Presence of matrix metalloproteinases and tissue inhibitor of matrix metalloproteinase in human sperm. $J$ Androl 2002;23:702-708. 
63. Huleihel M, Lunenfeld E, Levy A, Potashnik G, Glezerman M: Distinct expression levels of cytokines and soluble cytokine receptors in seminal plasma of fertile and infertile men. Fertil Steril 1996;66:135-139.

64. Gutsche S, von Woll M, Strowitzki T, Thaler CJ: Seminal plasma induces mRNA expression of IL-1 $\beta$, IL-6 and LIF in endometrial epithelial cells in vitro. Mol Human Reprod 2003;9:785-791.

65. Politch JA, Tucker L, Bowman FP, Anderson DJ: Concentrations and significance of cytokines and other immunologic factors in semen of healthy fertile men. Human Reprod 2007;22:2928-2935.

66. Soucek K, Slabakova E, Ovesna P, Malenowska A, Kozubik A, Hampl A: Growth/differentiation factor-15 is an abundant cytokine in human seminal plasma. Human Reprod 2010;25:2962-2971.

67. Bouraoui Mechergui Y, Ben Jemaa A, Mezigh C, Fraile B, Ben Rais N, Paiagua R, Royuela M, Oueslati R: The profile of prostate epithelial cytokines and its impact on sera prostate specific antigen levels. Inflammation 2009;32:202-210.

68. Ochsenkühn R, Toth B, Nieschlag E, Artman E, Friese K, Thaler CJ: Seminal plasma stimulates cytokine production in endometrial epithelial cell cultures independently of the presence of leucocytes. Andrologia 2008;40:364-369.

69. Martinez-Prado E, Camejo-Bermudez MI: Expression of IL-6, IL-8, TNF- $\alpha$, IL-10, HSP60, Anti-HSP-60 antibodies, and anti-sperm antibodies, in semen of men with leukocytes and/or bacteria. AJRI 2010;63:233-243.

70. Denison FC, Grant VE, Calder AA, Kelly RW: Seminal plasma components stimulate interleukin-8 and interkleukin-10 release. Mol Human Reprod 1999;5:220-226.

71. von Wolff M, Nowak O, Pinheiro RM, Strowitzki T: Seminal plasma.immunomodulatory potential in men with normal and abnormal sperm count. Eur J Obstet Gyn \& Reprod Biol 2007;134:73-78.

72. Suarez SS: Regulation of sperm storage ad movement in the mammalian oviduct. Int $J$ Dev Biol 2008;52:455-462.

73. Liberda J, Ticha M, Zraly Z, Svecova D, Veznik Z: Interaction of bull, stallion and boar seminal plasma proteins and sperms with acidic polysaccharides. Folia Biol (Praha) 1998;44:177-183.

74. Caballero I, Vazquez JM, García EM, Roca J, Martínez EA, Calvete JJ, Sanz L, Ekwall H, Rodríguez-Martínez H: Immunolocalization and possible functional role of PSP-I/PSP-II heterodimer in highly-extended boar spermatozoa. J Androl 2006;27:766-773. 
75. Dapino DG, Teijeiro JM, Cabada MO, Marini PE: Dynamics of heparin-binding proteins on boar sperm. Anim Reprod Sci 2009;116:308-317.

76. Vadnais ML, Roberts KP: Seminal plasma proteins inhibit in vitro- and cooling-induced capacitation oin boar spermatozoa. Reprod Fertil Dev 2010;22:893-900.

77. Töpfer-Petersen E, Ekhlasi-Hundrieser M, Tsolova M: Glycobiology of fertilization in the pig. Int J Dev Biol 2008;52:717-736.

78. van Gestel R, Brewis I, Ashton P, Helms J, Brouwers J, Gadella B: Capacitation-dependent concentration of lipid rafts in the apical ridge head area of porcine sperm cells. Mol Hum Reprod 2005;11:583-590.

79. van Gestel RA, Brewis IA, Ashton PR, Brouwers JF, Gadella BM: Multiple proteins present in purified porcine sperm apical plasma membranes interact with the zona pellucida of the oocyte. Mol Hum Reprod 2007;13:445-454.

80. Caballero I, Vazquez JM, Mayor GM, Almiana C, Calvete JJ, Sanz L, Roca J, Martinez EA: PSP-I/PSP-II spermadhesin exert a decapacitation effect on highly extended boar spermatozoa. Int J Androl 2009;32:505-513.

81. Poiani A: Complexity of seminal fluid: a review. Behv Ecol Sociobiol 2006;60:289-310.

82. Robertson SA, Guerin LR, Bromfield JJ, Branson KM, Ahlström AC, Care AS: Seminal fluid drives expansion of the CD4+CD25+ T regulatory cell pool and induces tolerance to paternal alloantigens in mice. Biol Reprod 2009; 80:1036-1045.

83. Sharkey DJ, Macpherson AM, Tremellen KP, Robertson SA: Seminal plasma differentially regulates inflammatory cytokine gene expression in human cervical and vaginal epithelial cells. Mol Hum Reprod 2007;13:491-501.

84. O’Leary S, Jasper MJ, Warnes GM, Armstrong DT, Robertson SA: Seminal plasma regulates endometrial cytokine expression, leukocyte recruitment and embryo development in the pig. Reproduction 2004;128:237-247.

85. Moldenhauer LM, Diener KR, Thring DM, Brown MP, Hayball JD, Robertson SA: Crosspresentation of male seminal fluid antigens elicits $\mathrm{T}$-cell activation to initiate the female immune response to pregnancy. J Immunol 2009;182:8080-8093.

86. Loras B, Vetele F, El Malki A, Rollet J, Soufir JC, Menahmed A: Seminal transforming growth factor- $\beta$ in normal and infertile men. Human Reprod 1999;14:1534-1539.

87. Robertson SA, Ingman WV, O'Leary S, Sharkey DJ, Tremellen KP: Transforming growth factor beta-a mediator of immune deviation in seminal plasma. J Reprod Immunol 2002;57:109-128. 
88. Robertson SA. Seminal plasma and male factor signalling in the female reproductive tract. Cell Tissue Res 2005;322:43-52.

89. O’Leary S, Armstrong D, Robertson S: Transforming growth factor- $\beta$ (TGF $\beta$ ) in porcine seminal plasma. Reprod Fertil Dev (in press).

90. Chu TM, Nocera MA, Flanders KC, Kawinski E. Localization of seminal plasma transforming growth factor-beta1 on human spermatozoa: an immunocytochemical study. Fertil Steril 1996;66:327-330)

91. Robertson SA, O’Leary S, Armstrong DT: Influence of semen on inflammatory modulators of embryo implantation. Soc Reprod Fertil Suppl 2006;62:231-245.

92. Robertson SA, Guerin LR, Molderhauer LM, Hayball JD: Activating T regulatory cells for tolerance in early pregnancy- the contribution of seminal fluid. J Reprod Immunol 2009; 83:109-116.

93. Robertson SA: Seminal fluid signalling in the female reproductive tract: lessons from rodents and pigs. J Anim Sci 2007;85:E36-44.

94. Dallas SL, Zhao S, Cramer SD, Chen Z, Peehl DM, Bonewald LF: Preferential production of latent transforming growth factor $\beta-2$ by primary prostatic epithelial cells and its activation by prostate-specific antigen. J Cell Physiol 2005;202:361-370.

95. Killian GJ, Chapman DA ,Rogowski LA: Fertility-associated proteins in Holstein bull seminal plasma. Biol Reprod 1993;49: 1202-1207.

96. Gerena RL, Irikura D, Urade Y, Eguchi N, Chapman DA ,Killian GJ: Identification of a fertility-associated protein in bull seminal plasma as lipocalin-type prostaglandin D synthase. Biol Reprod 1998;58: 826-833.

97. Cancel AM, Chapman DA ,Killian GJ: Osteopontin localization in the Holstein bull reproductive tract. Biol Reprod 1999;60: 454-460.

98. Hao Y, Mathialagan N, Walters E, Mao J, Lai L, Becker D, Li W, Critser J, Prather RS: Osteopontin reduces polyspermy during in vitro fertilization of porcine oocytes. Biol Reprod 2006;75: 726-733.

99. Hao Y, Murphy CN, Spate L, Wax D, Zhong Z, Samuel M, Mathialagan N, Schatten H, Prather RS: Osteopontin improves in vitro development of porcine embryos and decreases apoptosis. Mol Reprod Dev 2008;75:291-298.

100. Brandon CI, Heusner GL, Caudle AB, Fayrer-Hosken RA: Two-dimensional polyacrylamide gel electrophoresis of equine seminal plasma proteins and their correlation with fertility. Theriogenology 1999;52:863-873. 
101. Assreuy AM, Calvete JJ, Alencar NM, Cavada BS, Rocha-Filho DR, Melo SC, Cunha FQ, Ribeiro RA: Spermadhesin PSP-I/PSP-II heterodimer and its isolated subunits induced neutrophil migration into the peritoneal cavity of rats. Biol Reprod 2002;67:1796803.

102. Assreuy AMS, Alencar NMN, Cavada BS, Rocha-Filho DR, Feitosa RFG, Cunha FQ, Calvete JJ, Ribeiro RA: Porcine spermadhesin PSP-I/PSP-II stimulates macrophages to release a neutrophil chemotactic substance: modulation by mast cells. Biol Reprod 2003;68:1836-1841.

Hrm/2011 
Figure texts:

Figure 1: Protein composition of the seminal plasma of the sperm-peak portion (FI, upper panels) and the rest of the ejaculate (FII, lower panels) in representative boars. Protein profiles were characterized by reverse-phase HPLC separation (left panels), SDS-PAGE (insert in lower left panel), and 2D-electrophoresis (right panels). Chromatographic peaks and electrophoretic protein spots were characterized by $\mathrm{N}$-terminal sequencing and proteomic analysis, including MALDI-TOF tryptic peptide mass fingerprinting followed by collision-induced dissociation tandem mass spectrometric analysis of selected peptidic ions. Identified proteins are highlighted in the panels.

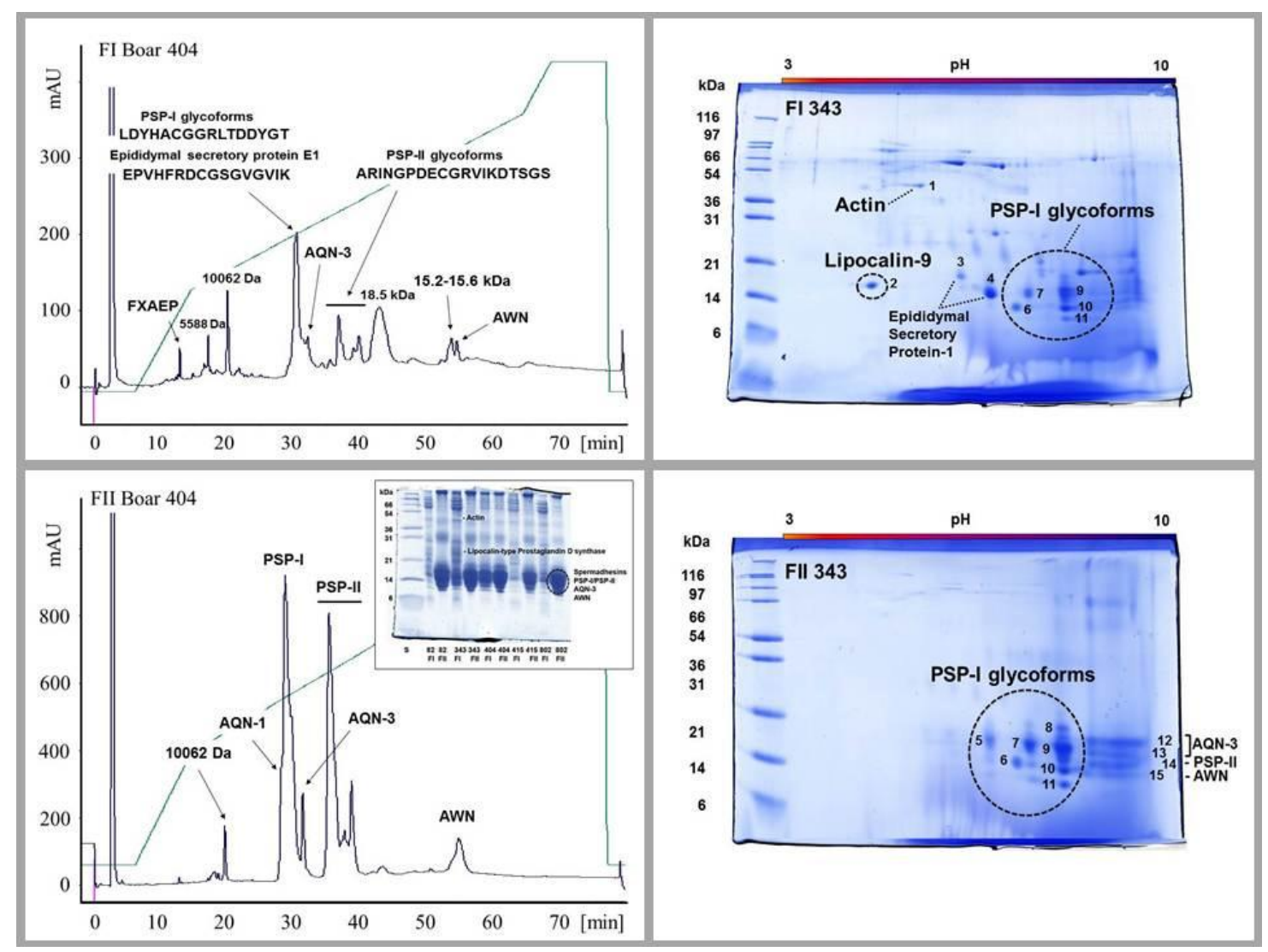


Figure 2: The emerging view is that the balance between cytokines released by macrophages (TNF $\alpha$ ) and mast cells (IL-4) controls the onset of neutrophil (PMN) migration in response to the inflammatory stimuli of PSP-I/PSP-II, thereby avoiding excessive PMN recruitment. This regulation seems crucial during situations where an excessive accumulation of PMNs would lead to tissue damage (i.e., in postmating endometritis) ${ }^{101,102}$.
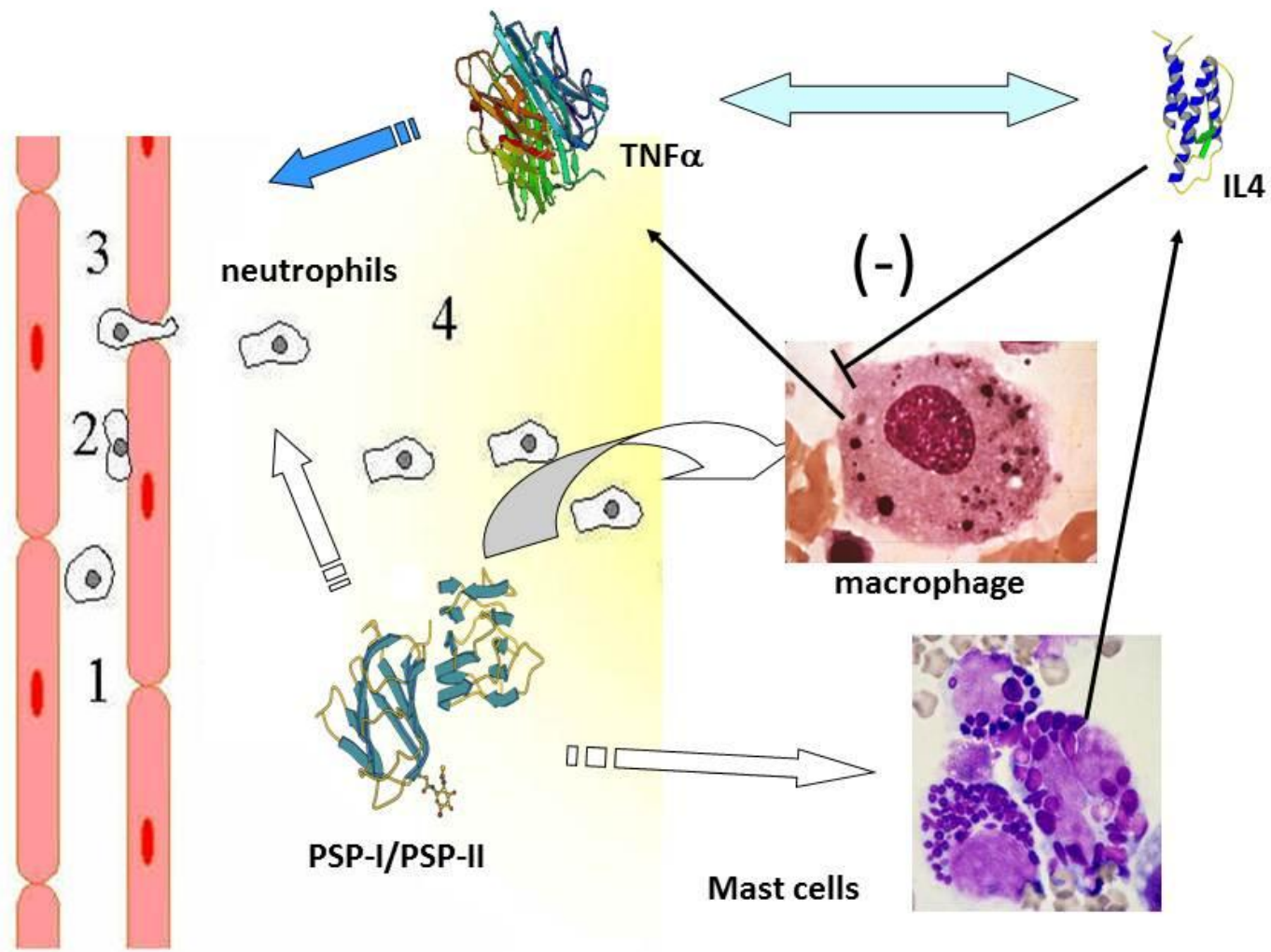